\title{
MUHAMAD KARNO KUSUMO DARMOKO PELOPOR KARAWITAN SRAGENAN
}

\author{
Robert Aris Widodo \\ Penggemar Karawitan Sragenen, tiingal di Sragen, Jawa Tengah
}

\begin{abstract}
Starting from an idea to reveal the creativity of the artist who spearheaded the emergence of Karawitan Sragenan, Muhamad Karno Kusumo Darmoko through the process of artistry with the art work. Sragenan style started when the karawitan in Sragen began to be displaced by Dangdutmusic (orkes Melayu).

Karno is one of the artists in Sragen who feel anxious about the situation and think about how to keep karawitan alive in Sragen. With the spirit of maintaining the existence of karawitan in Sragen and by having the educational background of art, Karno did some experimental process working on musical karawitan which culminate in an invention musical concept Sragenan style. Karno classifies that there are two concept of patterns in Sragenan style, they gecul and dangdut. The existence of Karawitan Sragenan style also has an impact on karawitan in Sragen, Sragen society and Muhamad Karno Kusumo Darmoko as the pioneer of Sragenan.
\end{abstract}

Kata kunci : M. Karno KD, karawitan, kreativitas, Sragenan

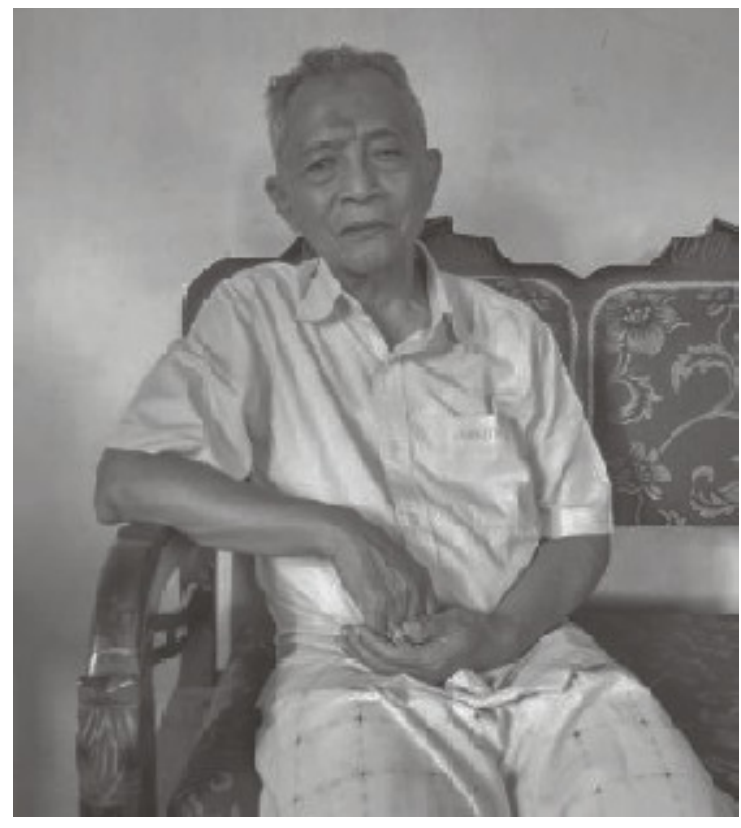

Gambar 1. Muhamad Karno Kusumo Darmoko (Foto : Robert, 2018)

\section{Profil Singkat Karno}

Muhamad Karno Kusumo Darmoko atau yang sering dikenal dengan nama $\mathrm{M}$. Karno KD. merupakan seorang seniman yang berpendidikan. Dia mengawali pendidikan formal di Sekolah Rakyat (SR) pada tahun 1949/1950 setelah berakhirnya perang dunia ke-2. Pada tahun 1955/1956. Karno tamat dari sekolah rakyat namun tidak langsung melanjutkan sekolah karena dari pihak keluarga tidak menghendakinya untuk melanjutkan sekolah karena orang tuanya menganggap hanya keluarga petani. 
Karno yang ingin tetap melanjutkan sekolah membuatnya bersikap berbeda terhadap keluarga karena keinginannya untuk memperoleh pendidikan tidak terpenuhi. Selama satu tahun Karno hanya menjadi anak gembala seperti anak-anak pada umumnya saat itu.

Pihak kelurga akhirnya menyetujui dan mengijinkan Karno untuk melanjutkan sekolah dan pada tahun 1956/1957 terdaftar di SMP Muhammadiyah Sragen yang lulus pada tahun 1959/1960. Setelah tamat dari SMP Muhammadiyah dia melanjutkan ke Konservatori Karawitan Indonesia Surakarta (SMK N 8 Surakarta saat ini) lulus pada tahun 1963 dan masuk Akademi Seni Karawitan Indonesia (ASKI) (perguruan tinggi seni pada saat itu dan sekarang menjadi ISI Surakarta) pada tahun 1964. Belum sempat menyelesaikan pendidikan dan baru sampai tingkat-2 terjadi pergolakan politik pada tahun 1965 yang dikenal dengan G30S/PKI dan menyebabkan proses pendidikan berhenti. Selama proses pendidikan terhenti, Karno kembali ke Sragen dan membentuk grup ketoprak setelah situasi dan kondisi sudah mulai normal. Pendidikannya di ASKI tidak terselesaikan karena pada saat di Sragen Karno diangkat menjadi seorang guru SPG (sekolah pendidikan guru) dan karena janjinya akan memberikan seluruh waktu, tenaga dan pikiran jika diangkat menjadi Aparatur Sipil Negara (ASN), maka beliau tidak bisa melanjutkan pendidikannya yang sudah tingkat-2 di ASKI.

Perjalanan atau riwayat berkesenian Karno dapat dikatakan baru dimulai sejak menempuh pendidikan formal di sekolah seni. Meskipun hidup di lingkungan seni, namun bakat seni yang dimiliki baru terlihat dan tersalurkan sejak masuk Konservatori Karawitan Indonesia Surakarta atau sering disebut dengan Kokar (SMK N 8 Surakarta saat ini). Dapat dikatakan demikian karena sebelumnya Karno tidak pernah menjadi pelaku seni. Sejak kecil Karno sudah bersinggungan dengan seni, akan tetapi dia hanya menjadi penikmat dan menyukai kesenian (tradisi) seperti seni pewayangan dan tari. Sekolah seni menjadi pilihanya sendiri tanpa dorongan orang terdekat, baik itu orang tua maupun kerabat. Berdasar pilihanya untuk menempuh pendidikan seni, Karno sebelumnya sudah memiliki bakat seni dalam dirinya. Seperti yang diungkapkan oleh Utami Munandar, bahwa tujuan pendidikan pada umumnya adalah menyediakan lingkungan yang memungkin kan peserta didik untuk mengembangkan bakat dan kemampuan secara optimal, sehingga dia dapat mewujudkan dirinya dan berfungsi sepenuhnya, sesuai dengan kebutuhan pribadinya dan masyarakat (2002: 4).

Karno kurang mendapat dukungan dari keluarga bahkan orang tua sejak awal masuk Kokar. Orang tuanya menghendaki 
Karno hanya bersekolah sampai Sekolah Rakyat (SD saat ini). Setelah lulus Sekolah Rakyat (1955/1956), Karno tidak diperkenankan untuk melanjutkan sekolah dan hanya menjadi anak gembala seperti kebanyakan anak lainnya pada saat itu. Tekatnya untuk bersekolah sangat besar dan selama tidak bersekolah, Karno menjadi anak yang morsal (tidak menurut kepada orang tua) karena keinginannya untuk bersekolah tidak disetujui. Menyadari keinginan dan niat dari Karno begitu bersemangat untuk bersekolah, akhirnya orang tuanya pun mengijinkan dan membiayai untuk melanjutkan sekolah ke tingkat SMP.

Perjuangan Karno untuk melanjutkan sekolah dan menuntut ilmu tidak hanya sebatas melawan keinginan orang tuanya. Ketika akan melanjutkan sekolah di Konservatori, Karno tidak sedikit mendapat sindiran dan cemoohan dari teman sebaya ketika naik kereta untuk berangkat ke Solo. Hal tersebut terjadi karena Karno melanjutkan pendidikannya di sekolah seni. Berbekal kecintaannya terhadap seni dan bertekat bersekolah setinggi mungkin menguatkan mentalnya dan menahan sindiran yang diterimanya.

Bersekolah di bidang seni sungguh berat rasanya yang dialami oleh Karno. Berat dalam arti bukan tugas dari sekolah melainkan suara-suara berupa sindiran yang dia terima serta kurangnya dukungan dari pihak keluarga yang dapat menjatuhkan mental Karno untuk tetap bersekolah seni dan berkiprah di dunia seni. Salah satu contoh sindiran atau ungkapan yang bersifat kurang mendukung berasal dari pamannya yaitu "sekolah neng seni arep dadi apa?". Pertanyaan tersebut memiliki arti bersekolah di seni mau menjadi apa nantinya (ke depannya), karena memang pada saat itu dunia seni tidak dapat dijadikan sebagai pijakan utau tumpuhan hidup (Karno, wawancara 18 Februari 2017).

Mendapatkan sindiran bahkan dari keluarga tidak menjadikan Karno putus asa dan hilang semangat untuk bersekolah, namun semakin menjadikan dirinya optimis dan akan membuktikan terhadap keluarga bahwa menjadi seniman juga merupakan pekerjaan yang pantas disejajarkan dengan pekerjaan lainnya. Selain apa yang telah dia ungkapkan, Karno mempunyai tujuan yang sangat mulia yaitu ingin menjadi seorang guru. Cita-citanya ingin menjadi seorang guru karena melihat minimnya tenaga pendidik pada saat itu dan kurang meratanya pendidikan.

Setelah menjadi salah satu murid di Kokar, bakat Karno di bidang seni mulai terlihat dan selalu dia kembangkan. Salah satu prestasi yang cukup membanggakan yaitu menjadi atau berperan sebagai penari Cakil dalam acara tari kolosal Ramayana ke- 
dua yang diselenggarakan di Candi Prambanan. Hal ini menjadi sesuatu yang sangat membanggakan untuknya karena Karno merasa banyak murid lainnya yang tariannya lebih bagus dibanding dia, namun justru Karno yang dipilih.

Selain menjadi pemeran Cakil dalam tari kolosal Ramayana, Karno juga pernah ikut Indonesian Arts Management (IAM) dan mengadakan pentas di Amerika, namun pentas tersebut batal karena Indonesia ke luar dari Perserikatan Bangsa-Bangsa (PBB) yang membuat hubungan IndonesiaAmerika putus. Ketika ikut IAM, Karno ke luar dari Ramayana yang sebenarnya sudah dilarang oleh ketua Kokar yaitu Gusti Pangeran Haryo Joyo Kusumo. Ibarat sudah jatuh tertimpa tangga, IAM batal pentas di Amerika dan setelah kembali ke sekolah, Karno berserta beberapa temannya mendapat surat yang berisi sangsi tidak boleh sekolah selama dua bulan. Setelah mendapat sangsi tersebut Karno kemudian pulang dan belum genap dua bulan, tepatnya baru tiga minggu ada utusan dari sekolah datang ke rumah memberi kabar bahwa Karno dipanggil Gusti Pangeran Haryo Joyo Kusumo untuk melanjutkan sekolahnya.

Dapat dikatakan bahwa masa bersekolah di Kokar merupakan langkah awal perjalanan Karno berkiprah di dunia seni dan memulai proses kesenimanannya. Beberapa bentuk kesenian dia pelajari, seperti seni tari, karawitan dan pewayangan semasa berekolah di Konservatori. Selepas lulus dari Kokar, kemudian Karno melanjutkan pendidikan seninya di ASKI. Selama menjadi mahasiswa ASKI bakat dan jiwa seninya semakin diasah agar Karno memiliki bekal untuk mewujudkan citacitanya menjadi seorang guru.

Keadaan politik yang kurang kondusif di Indonesia pada saat itu (1965) membuat segala bentuk kegiatan terhenti tidak terkecuali proses pendidikan. Karno juga terpaksa kembali ke rumah karena tidak adanya kegiatan belajar-mengajar dan sambil menunggu keadaan kembali normal. Selama berada di rumah, Karno membentuk grup Ketoprak serta mengajar seni tari di SMP Muhammadiyah Sragen. Materi yang diajarkan oleh Karno yaitu tari Kuda-Kuda, Pejuang dan tari kreasi baru. Bertepatan dengan Hari Pendidikan Nasional, di gedung Dewan Perwakilan Rakyat Daerah (DPRD) Sragen diadakan pentas yang dihadiri guru-guru serta pegawai dinas Kabupaten Sragen dan yang menjadi salah satu penampil dalam acara tersebut adalah perwakilan dari SMP Muhammadiyah Sragen. SMP Muhammadiyah Sragen menampilkan beberapa tarian yang termasuk dalam kategori tari kreasi baru, seluruh penari maupun pengrawitnya adalah anak-anak.

Pada waktu perwakilan dari SMP Muhammadiyah tampil membuat gempar 
seluruh penonton dan para tamu undangan yang menyaksikannya. Kejadian tersebut bukan tanpa alasan, karena sebelumnya belum pernah disajikan tari kreasi baru, hanya ada pementasan tari klasik seperti tari Gambir Anom, Gatut Kaca Gandrung, Kelono dan lainnya. Salah satu tarian yang membuat antusiasme penonton meningkat termasuk kepala SGA atau SPG (sekolah pendidikan guru) yaitu tari kuda-kuda. Setelah berakhirnya acara tersebut membuat kepala SPG mencari informasi siapa pelatih atau guru yang mengajar. Berselang waktu satu minggu dari acara tersebut Karno dipanggil oleh kepala SPG untuk diwawancari termasuk pendidikan terakhirnya. Dalam pertemuan tersebut Karno diberi tawaran untuk menjadi guru Seni Budaya (Karno, wawancara 19 Februari 2017).

Menjadi pengajar tari sudah dilakoni sejak awal masuk ASKI yang mengharuskan dia untuk pandai membagi waktu. Hal ini dapat dilakukan 61 karena proses kegiatan belajar-mengajar di ASKI dimulai sore hari, sehingga pagi harinya dapat digunakan Karno untuk mengajar di Sragen. Setelah situasi dan kondisi negara berangsur membaik, malah terjadi benturan jadwal yaitu ASKI yang semula proses kegiatannya dimulai sore hari berubah menjadi pagi sampai sore hari, dengan begitu Karno harus memilih salah satu antara meneruskan belajar di Surakarta atau mengajar di Sragen. Akhirnya Karno memilih untuk tetap melanjutkan pendidikannya di ASKI.

Awal proses pendidikannya bertepatan dengan pertemuan dengan kepala SPG yang menawarinya menjadi seorang guru. Karno merasa kembali dihadapkan dengan pilihan yang menurutnya sulit. Setelah melalui proses pertimbangan, Karno akhirnya menyetujui tawaran untuk menjadi guru SPG dengan syarat langsung diangkat menjadi Pegawai Negeri Sipil (PNS). Melihat kemampuan yang dimiliki oleh Karno sangat dibutuhkan, kepala SPG menyetujui sebuah kesepakatan yang berujung Karno harus berhenti bersekolah dan menjadi tenaga pendidik di SPG yang langsung diangkat menjadi Pegawai Negeri Sipil atau sekarang berubah nama menjadi Aparatur Sipil Negara (ASN).

Selama bersekolah di Surakarta, dengan keadaan seadanya Karno tetap bersemangat meskipun harus tinggal menumpang di tempat orang yang menurutnya jauh dari kata layak. Karno tidak merasa malu dengan proses hidupnya selama menempuh pendidikan di luar kota dan jauh dari keluarga. Hal ini diungkapkan bahwa dia pernah tinggal di tempat orang yang memiliki usaha produksi peralatan memasak dengan tempat seadanya yang hanya beralaskan tikar, bahkan ketika hujan seringkali atapnya bocor. Semua dilakukan 
dengan tanpa rasa malu karena sudah menjadi jalan pilihannya untuk menuntut ilmu setinggi mungkin sebagai bekal mewujudkan cita-citanya.

\section{Gaya Sragenan}

Dalam seni karawitan gaya Sragenan ini begitu populer di masyarakat. Hal ini terlihat dari masyarakat yang banyak mengenal istilah kata Sragenan dan tidak hanya masyarakat Sragen sendiri sebagai pemilik budaya musik, namun kabupaten sekitar Sragen juga sudah mengenal istilah Sragenan. Mengenal kata Sragenan belum tentu mengerti apa yang dimaksud dengan Sragenan sebagai garap musikal karawitan dan sejarah adanya Sragenan yang eksistensinya masih bertahan sampai saat ini. Awal kemunculannya mendapat respon yang kurang baik dari para seniman karawitan karena Sragenan dianggap telah merusak citra karawitan yang terkenal sebagai kesenian adiluhung.

Pandangan yang menganggap Sragenan merusak "tradisi" dilandasi oleh anggapan bahwa karawitan identik dengan kehalusan sesuai makna kata karawitan yang diambil dari istilah rawit yang berarti halus. Karno juga menyebutkan bahwa ada sebuah filosofi "belajar karawitan berarti belajar kehalusan". Filosofi tersebut seperti tidak berlaku untuk karawitan Sragenan yang terkenal meriah atau istilah lokal menyebutnya "gayeng" di setiap pergelarannya.

Meskipun dianggap sebagai perusak kesenian tradisi, Karno merasa bangga karena mendengar ungkapan dari Ketua Akademi Seni Karawitan Indonesia (ASKI) Gendon Humardani yaitu "Kalau kamu mengatakan Karno sebagai perusak seni (karawitan) itu keliru, justru Karno berjasa menambah khasanah budaya. Sebelumnya tidak ada menjadi ada dan dikenal masyarakat luas dan diakui Dirjen Kebudayaan, bahkan sampai digunakan sebagai bahan/materi seminar di Filipina" (Karno, wawancara 17 Februari 2017).

Seperti yang diketahui, gaya musikal Sragenan ada sejak dekade 1980-an dan eksistensinya masih bertahan sampai sekarang. Orang yang berjuang dan berperan dalam tercetusnya istilah Sragenan adalah Karno melalui karya-karyanya. Karya lagu atau gending badhutan gaya Sragenan ciptaannya menjadi hits bahkan membuat geger dunia karawitan. Alasan beliau menciptakan gending-gending Sragenan adalah karena keprihatinanya ketika melihat keadaan karawitan cokèkan di Sragen pada waktu itu cenderung tidak mendapat perhatian dari masyarakat pendukungnya (Suparno, 1997:22).

Bentuk sajian gending-gending garap Sragenan sesungguhnya tidak 
memiliki perbedaan dengan bentuk gending yang sudah ada sebelumnya. Karawitan Sragenan merupakan sebuah fenomena perkembangan musik tradisional Jawa yang berakar dari karawitan tradisi. Bentuk gending yang sering ditampilkan dengan garap Sragenan adalah bentuk: Ladrang, Ketawang, Lancaran, Jineman, Langgam, dan Lagon. Menurut Sudarni masyarakat di wilayah Sragen telah mengenal gendinggending Badhutan sebelum tahun 1965 (Sudarni, 2002:67).

Sebelum Karno membuat karya lagu Sragenan, di awal percobaannya Karno menggarap repertoar lagu dari musik dangdut yang berjudul Mawar Merah. Rasa yang diperoleh dianggapnya kurang begitu pas karena perbedaan wilayah nada. Lagu yang diaransemen merupakan lagu bertangga nada diatonis sedangkan penggarapan menggunankan tangga nada pentatonis. Selain mencoba menggarap lagu dangdut, Karno juga menggarap gendinggending yang sudah ada pada masa karawitan Gong Gongpo. Akhirnya Karno memutuskan untuk membuat karya lagu sendiri dan karya pertamanya berjudul "Goyang Pinggul”.

Karawitan Sragenan oleh Karno diklasifikasikan menjadi dua jenis garap dalam sajiannya, yaitu garap gecul dan garap dangdut. Garap gecul juga dikenal dengan istilah lain yaitu badhutan. Gecul sendiri bermakna lucu, sehingga dalam penyajiannya selalu diikuti dengan hal-hal yang mengundang kelucuan. Kelucuan yang dihadirkan bisa saja dari interaksi vokal dengan penjoget dan juga interaksi pengendang melalui pola sekarannya yang menimbulkan gerakan-gerakan lucu dari penjoget.

Garap dangdut pada karawitan Sragenan awalnya merupakan sebuah transmedium dari musik dangdut bernada diatonis ke gamelan yang bernada pentatonis. Tidak sedikit yang mengatakan bahwa Sragenan yang diracik oleh Karno meniru gending dangdut karya Ki Narto Sabdo karena keduanya dirasa sama. Walaupun ada kesamaan antara garap dangdut Sragenan dengan gending dangdut karya Ki Narto Sabdo, namun ada yang membedakan di antara keduanya. Hal ini diungkapkan oleh Karno bahwa gendinggending dangdut karya Narto Sabdo enak di dengar sedangkan gending dangdut Sragenan yang dia ciptakan enak untuk dijogeti. Ungkapan tersebut bukan tanpa sebuah landasan, karena dalam proses mencari pola kendangan selalu disertai dengan pola jogetan.

Pada awal proses Karno dalam membuat dan menggarap gending dangdut media yang digunakan murni perangkat 
gamelan ageng tanpa memasukkan instrumen tambahan ke dalamnya. Seiring perkembangan dan munculnya senimanseniman muda, terdapat penambahan instrumen 50 seperti kendang Sunda. Posisi kendang Sunda yang miring memunculkan istilah ndang dimiringké yang berarti bahwa penonton menginginkan garap Sragenan.

Tujuan memasukkan kendang jaipong Sunda ini adalah menambah inovasi dalam seni karawitan yang terwujud dalam Sragenan hanya karena keprihatinan Karno terhadap kondisi seni karawitan. Tanpa disadari dengan adanya gaya Sragenan sedikit banyak dapat memberikan keuntungan secara komersil untuk dirinya sendiri maupun orang lain berupa materi (uang) yang dia peroleh dari hasil mencipta lagu yang kemudian direkam. Perekaman oleh pihak produser juga bersifat saling menguntungkan. Produser mendapatkan hasil dari penjualan kaset dan dengan beredarnya kaset tersebut nama Sragenan semakin dikenal masyarakat luas.

Gaya Sragenan lebih menekankan pada rasa gayeng dan enak untuk dijogeti. Terbukti disetiap pementasannya selalu nampak meriah dan ramai. Kegaduhan yang sering terjadi lebih kepada kemeriahan suarasuara dari penonton dan penjoget yang timbul karena kelucuan-kelucuan atau rasa "gayeng" itu sendiri.

\section{Lingkungan Seni yang Mempengaruhi Pertumbuhan Muhamad Karno Kusumo Darmoko sebagai Seniman}

Pertumbuhan kesenimanan Karno dipengaruhi oleh lingkungan pergaulan seni yang dia ikuti. Beberapa lingkungan yang digaulinya bahkan mempengaruhi kecenderungan karakter dari gagasangagasan dan karya kreatif yang dia cetuskan. Sejak muda, Karno memiliki kesukaan dan apresiasi yang tinggi terhadap kesenian tayub. Dia mengaku sebagai penikmat yang fanatik terhadap seni Tayub. Sejak kecil, dia selalu menonton pertunjukan tayub di wilayah Sragen yang terjangkau oleh mobilitasnya. Wujud kesukaannya terhadap Tayub ditampakannya dengan selalu ikut ngibing atau berjoget dengan ledek Tayub. Hobi berjoget pada saat menonton pertunjukan Tayub dia lakukan hingga dewasa.

Ketika dewasa, posisi Karno sebagai penikmat tidak hanya dilakukan dengan menonton dan ikut berjoget, tetapi dia mulai terlibat sebagai panjak atau pengrawit Tayub. Kemampuannya sebagai panjak selain diperoleh dari pendidikan konservatori, juga dipengaruhi dari pengalaman melihat pertunjukan Tayub. Setiap kali tetangga, kerabat, dan orangorang dalam lingkungan pergaulannya membutuhkan panjak, dia secara sukarela 
akan turut serta terlibat dalam sebuah pementasan Tayub meski tidak ada imbalan sekalipun.

Pada masa itu (tahun 1950-an), populasi kesenian Tayub dan intensitas pertunjukannya sangat banyak di wilayah Sragen. Hampir setiap desa memiliki perangkat gamelan dan pelaku pertunjukan Tayub. Sehingga dimungkinkan pengalaman pentas sebagai panjak Karno cukup banyak dilakukannya dan berpengaruh terhadap pendewasaan kemampuan musikalitasnya. Selain memiliki pengalaman pentas sebagai panjak, Karno juga menjadi pelatih tari Tayub (Karno, wawancara 18 Februari 2017).

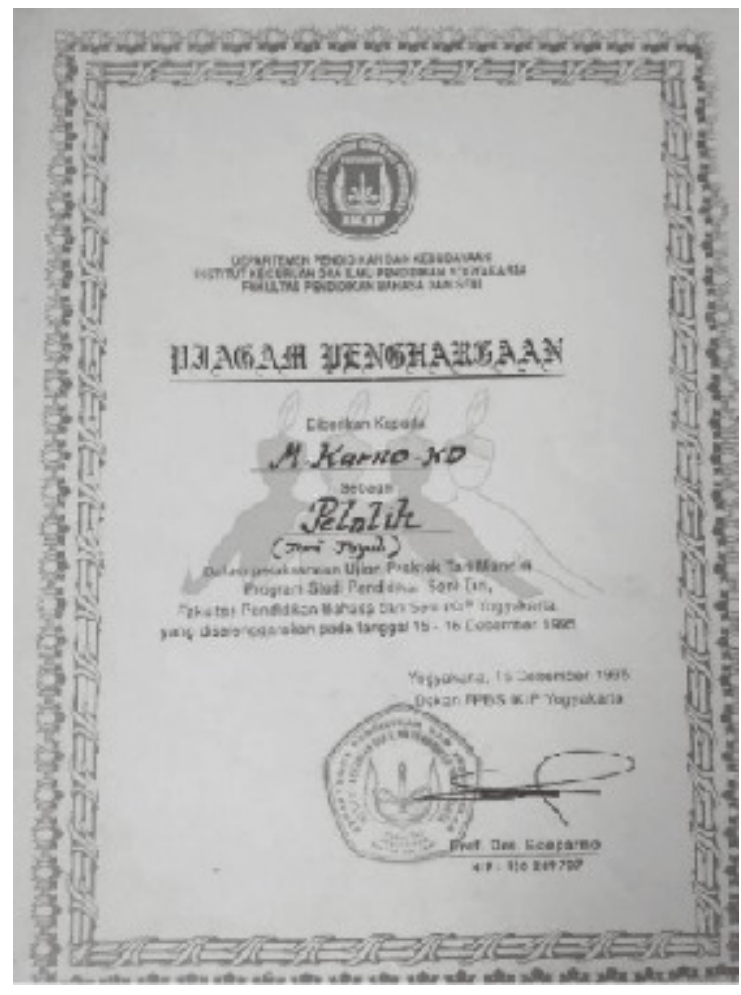

Gambar 2. Piagam Penghargaan sebagai Pelatih Tari Tayub (Foto: Robert, 2017)
Berada di lingkungan seni Tayub, rupanya menjadi bekal Karno dalam berinovasi mengembangkan karawitan di Sragen. Kesukaannya dan intensitas keterlibatan di lingkungan Tayub yang cukup tinggi, membuat Karno berinisiatif untuk memasukkan elemen musikal Tayub (garap gecul) ke dalam Karawitan yang akhirnya menciptakan Gaya Sragen yang populer dengan nama Sragenan. Inisiatif memasukkan unsur musikal Tayub tersebut bukan berarti serta merta memindahkan bentuk-bentuk musikal Tayub pada karawitan, tetapi Karno juga melakukan berbagai langkah penyesuaian dan pengembangan terhadapnya. Selain itu, bentukbentuk pengembangan musikal yang dilakukan Karno pada karawitan selalu mengedepankan karakter-karakter musikal yang enak untuk dijogeti. Hal ini tidak terlepas dari hobinya berjoget yang dia lakukan sejak masih kecil di lingkungan pertunjukan Tayub.

\section{Pengalaman Berkesenian}

Memiliki pengalaman dan pengetahuan dalam hal seni terutama seni Tayub, cukup memberi bekal dirinya untuk turun menjadi soerang seniman karawitan. Selain itu sejak kecil juga sudah berada di lingkungan yang masih subur kesenian tradisinya. Karno selalu mempelajari karawitan bahkan mampu memunculkan 
formula baru dalam bentuk gaya musikal. Gaya musikal dalam seni karawitan yang dia pelopori menjadi identitas musikal tersendiri sama halnya dengan karawitan Gaya Surakarta, Semarangan, Banyumasan, Banyuwangèn dan lainnya yang sama-sama menginduk pada seni karawitan.

Keprihatinan dan ketakutan Karno terhadap kelangsungan hidup dan eksistensi karawitan di Sragen yang mulai tergeser, memunculkan kreativitasnya dalam mengkonsep musikalisasi karawitan. Kemunduran seni karawitan menurut Karno akan berdampak pada kesenian lain yang di dalamnya terdapat unsur karawitan seperti seni Tayub dan Pewayangan, sehingga memicu ketakutannya terhadap hilangnya kebudayaan Jawa terutama seni tradisi. Dengan hilangnya seni tradisi, hal ini juga akan berdampak terhadap pengetahuan generasi penerus yang tidak akan mengetahui bahkan memiliki kesenian sebagai salah satu produk budaya (Jawa).

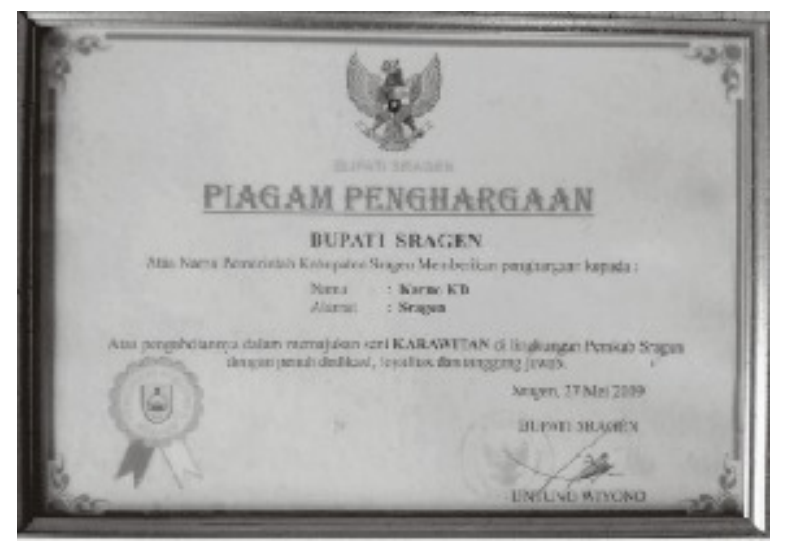

Gambar 4. Piagam Penghargaan dari Bupati Sragen sebagai Tokoh yang Memajukan Seni Karawitan di Sragen (Foto:Robert, 2017)
Sebagai salah satu bentuk respon terhadap keadaan yang terjadi, Karno membentuk sebuah paguyuban sebagai wadah dan media untuk mempertahankan seni karawitan yang diberi nama "Sekar Puri" pada tahun 1974. Sekar Puri beranggotakan para seniman-seniman yang dikumpulkan serta seniman muda sebagai generasi penerus yang nantinya akan menjadi pemilik seni karawitan sebagai bagian dari budaya masyarakat Jawa. Paguyuban yang dibentuk oleh Karno ini tidak hanya berisikan remaja putra, tetapi setelah berkembang juga terdapat anggota putri sehingga yang mulanya "Sekar Puri" yang memiliki kepanjangan "Seni Karawitan Putra Indonesia" berubah menjadi "Seni Karawitan Putra Putri". Kelompok seni karawitan ini menjadi salah satu media Karno dalam berkarya sekaligus senjata untuk mempertahankan seni karawitan di Sragen yang hampir mati saat itu (dekade '70an).

Paguyuban "Sekar Puri” cukup aktif di dunia karawitan karena selain sebagai tempat berkumpul dan berlatih karawitan, tetapi juga menerima job untuk mengisi acara hajatan. Selain itu "Sekar Puri” juga mengikuti kegiatan-kegiatan lomba, salah satunya lomba cokek se-Jawa Tengah yang diselenggarakan oleh Dinas Pendidikan Jawa Tengah pada tahun 1989. "Sekar Puri” menjadi aset penting yang dimiliki oleh 
Karno setelah keberadaan seni karawitan mulai dilupakan masyarakat yang pada waktu itu sedang menggemari musik dangdut.

Pada saat Karawitan Sragenan mulai digemari ditandai dengan terkenalnya gending yang berjudul "Rèwèl", Dinas Pariwisata kota Surakarta memberi kesempatan "Sekar Puri” untuk ikut mengisi acara maleman di Sriwedari. Pentasnya oleh Karno diberi judul "Pentas Taladhut", yaitu pentas tari, lagu, dan badhutan. Pertama kali pentas dipandang sebelah mata karena dibuatkan panggung di belakang gedung wayang orang. Tempatnya sangat kecil serta berada paling belakang pada komplek Sriwedari, namun penonton yang datang ternyata sangat banyak dan berdesakdesakan. Setelah dua hari, ada petugas dari Sriwedari datang dan menghendaki "Sekar Puri” yang semula pentas di belakang berpindah ke pendopo.

\section{Konsep Sragenan \\ Muhamad Karno Kusumo Darmoko}

Sub bab ini diuraikan beberapa gagasan atau konsep seni yang dicetuskan oleh Karno sebagai dasar pengembangan kreativitas di bidang karawitan Sragenan. Konsep-konsep tersebut diakui sebagai buah pemikiran dari Karno yang akhirnya menjadi salah satu dasar terciptanya
Karawitan Sragenan. Beberapa konsep penting yang terungkap di dalam penelitian ini antara lain adalah garap musikal (garap gecul dan dangdut) dan garap non musikal (penampilan seniman dan tata panggung).

\section{Konsep Garap Musikal}

Setelah segala bentuk seni karawitan tergeser keberadaannya oleh kesenian dangdut atau Orkes Melayu pada dekade 1970-an, Karno merasa prihatin dengan keadaan tersebut. Sebagai bentuk respon terhadap kemunduran seni karawitan, Karno pernah mencoba menggarap salah satu lagu dangdut menggunakan media gamelan, akan tetapi belum bisa menarik minat masyarakat pada saat itu. Masyarakat terutama kalangan pemuda masih tetap antusias dan responsif ketika pertunjukan dalam sebuah hajatan adalah musik dangdut dibandingkan karawitan. Mengetahui hal tersebut Karno merasa harus mencari ide lain agar karawitan mampu kembali di tengah-tengah masyarakat. Melalui beberapa percobaan garap musikal yang dilakukan dan akhirnya menemukan sebuah bentuk yang diramu dengan menggunakan bahan garap iringan gecul atau badhutan pada tari Tayub. Tari Tayub memiliki tiga bagian sajian yaitu tari Alus, Gagahan dan bagian Badhutan yang dijadikan salah satu ide konsep oleh Karno dalam masa percobaannya. 
Terdapat dua model garap sebelum muncul istilah Sragenan yang ditemukan Karno, yaitu bermaterikan gending badhutan yang penggarapannya menggunakan garap gecul dan garap dangdut. Garap gecul memberi warna bentuk sajian yaitu terkadang musik berhenti di tengah-tengah dan diikuti pula berhetinya para penjoget. Ketika musik berhenti merupakan sebuah kesepakatan dari para niyaga yang diberi aba-aba atau kode oleh pengendang. Berhenti pada bagian lagu yang mana atau berhenti berapa kali juga tergantung dari pengendang, sehingga dalam pertunjukan Karawitan Sragenan yang berperan penting dalam jalannya pergelaran adalah pengendang.

Gending-gending yang dimainkan dengan menggunakan garap gecul pada mulanya merupakan gending yang ada dalam Karawitan Gongpo dan gending dolanan. Dengan adanya garap gecul, sedikit demi sedikit karawitan mulai mendapat perhatian masyarakat. Kemudian setelah mendapat respon, Karno mencoba membuat karya lagu sendiri salah satunya berjudul Goyang Pinggul pada tahun 1979 yang masih menggunakan garap Gecul sehingga dikenal sebagai Gending Geculan. Setelah menciptakan lagu pertama, lahir karya lagu yang kedua berjudul 'Cewe' Ndeso" yang sudah digarap menggunakan irama dangdut. Pada mulanya mendapatkan respon yang berupa kritikan karena garap dangdut menggunakan media gamelan. Salah satu ungkapan yang cukup melekat pada ingatan Karno yaitu "Apa ya pénak lagu dangdut nganggo gamelan". Ungkapan tersebut mengandung unsur yang mengkritik kreativitas Karno dalam menggarap lagu dangdut menggunakan perangkat gamelan. Pertayaan tersebut memiliki arti "Apa ya enak lagu dangdut dimainkan dengan gamelan" (Karno, wawancara 18 Februari 2017).

Mendapat kritikan tersebut tidak membuat dirinya berhenti memberi sentuhan-sentuhan pada garap musikal untuk menjaga kebertahanan karawitan yang keberadaanya mulai tergeser. Karno kembali memasukkan konsep "mandhegmlaku atau mlaku-mandheg" tinggal dimulai dari mlaku atau mandheg. Konsep garap tersebut memiliki arti kendangan jogetan mandheg dan jogetan mlaku. Artinya jogetan mandheg yaitu joget berdiam di tempat, dan jogetan mlaku yaitu joget berpindah tempat atau berjalan. Konsep garap musikal inilah yang selanjutkan dipertahankan oleh Karno sebagai salah satu kreativitas dalam proses penggarapan gendinggending atau lagu ciptaannya.

Dalam konsep mandheg-mlaku atau sebaliknya, pengendang yang berperan penuh untuk mengatur dan mengendalikan 
jalannya sajian. Kreativitas dan ketrampilan pengendang disalurkan melalui aksen-aksen atau sekaran kendangan yang mampu diikuti oleh penjoget. Penjoget akan berteriak sebagai bentuk pujian terhadap pengendang ketika mereka merasa puas dan suka dengan kendangan yang disuguhkan. Beberapa teriakan yang sering terdengar yaitu "wah jos", "penak tenan" dan "ra rugi sing nanggap”.

Berikut merupakan contoh sekaran kendangan yang mengandung unsur jogetan mandheg-mlaku (Karno, wawancara 18 Februari 2017):

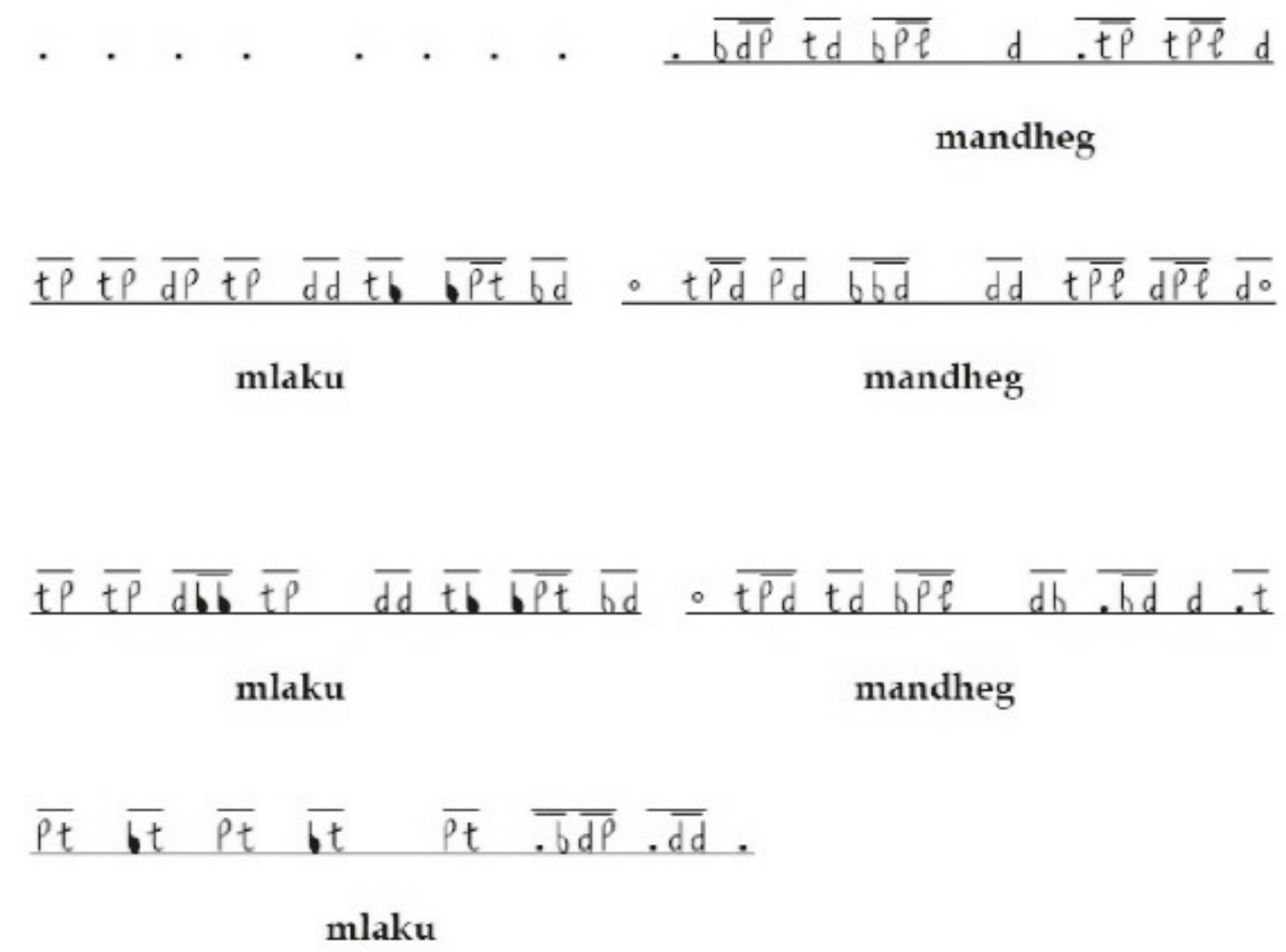

Dua unsur musikal yang dimasukkan oleh Karno menjadi cikal bakal yang melahirkan gaya musikal Sragenan sebagai materi garap dan selanjutnya dia membuat gending atau lagu dalam Karawitan Sragenan. Konsep gecul lebih kepada sajian musikal dalam pertunjukan karawitan. Unsur-unsur kelucuan digunakan untuk membangun suasana dan interaksi antara niyaga dan penjoget serta seluruh masyarakat yang hadir meskipun hanya menjadi penonton. 


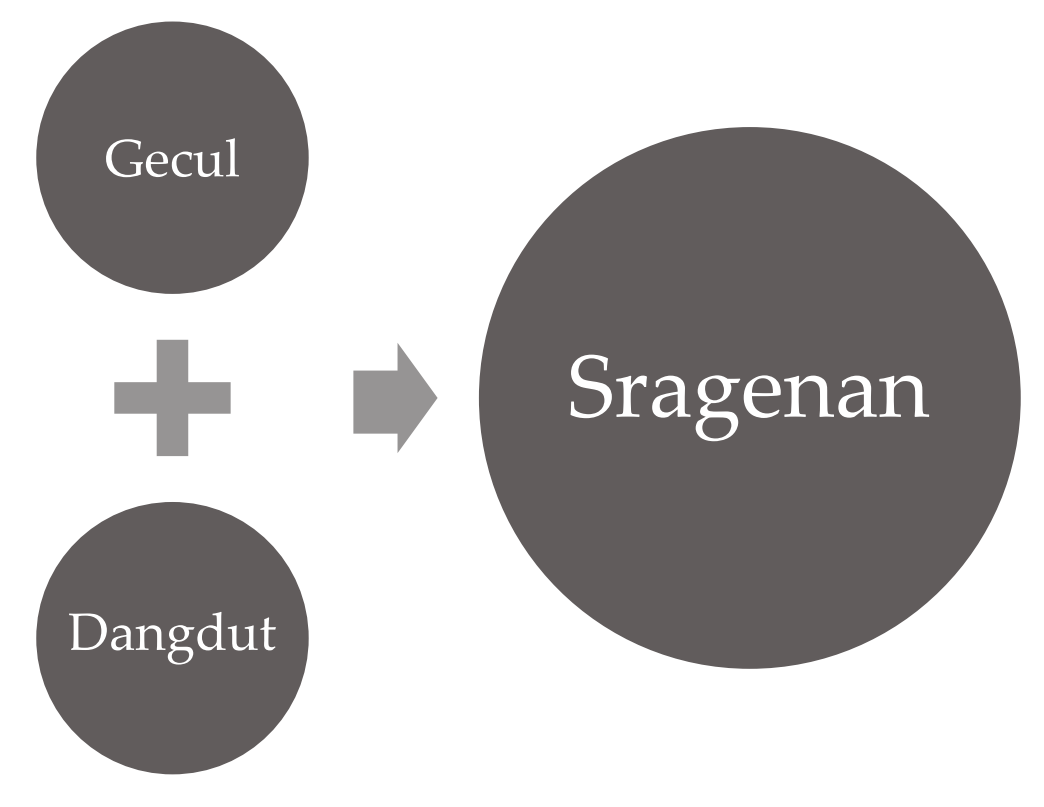

Bagan 1: Bagan di atas merupakan gambaran dua unsur garap musikal yang menjadi pijakan sehingga tercipta komposisi musikal karawitan gaya Sragenan.

Kedua garap tersebut yaitu garap gecul dan garap dangdut pada karawitan sragenan masih terikat oleh pakem struktur gending seperti Lancaran, Ketawang dan Ladrang yang ada. Seperti dijelaskan Sri Hastanto melalui buku yang berjudul Konsep Pathet Dalam Karawitan Jawa, bahwa Lancaran setiap gongan terdiri atas satu kalimat lagu dan kalimat lagu terdiri atas 16 sabetan (4 gatra). Untuk Ketawang, setiap gongan terdiri atas 2 kalimat lagu dan setiap kalimat lagu terdiri dari 8 sabetan (2 gatra), sedangkan Ladrang disetiap gongan terdiri dari 4 kalimat lagu dan setiap kalimat lagu terdiri atas 8 sabetan (2 gatra). Meskipun memiliki struktur gending yang sama, kedua sistem garap tersebut memiliki perbedaan yang terletak pada garap masingmasing instrumen seperti Bonang Barung, Bonang Penerus, Demung, Saron, Saron Penerus, Kempul dan Gong.

Satu gongan Lancaran Manyar Sewu akan digunakan sebagai contoh serta melihat letak perbedaan antara garap gecul dan garap dangdut melalui beberapa instrumen yang disebutkan di atas.

$$
\text { - } 5 \cdot \hat{3} \cdot \tilde{5} \cdot \hat{3} \cdot \tilde{5} \cdot \hat{3} \cdot \tilde{6} \cdot(5)
$$

Dari satu gonggan notasi Lancaran Manyar Sewu di atas, pola permainan atau instrumen yang mengalami perubahan garap pada garap gecul dan dangdut sebagai berikut. 


\section{Garap Gecul}

Bal: $\cdot 5 \cdot \hat{3} \cdot \overline{5} \cdot \hat{3} \cdot \frac{5}{5} \cdot \hat{3} \cdot \frac{6}{6} \cdot(5)$

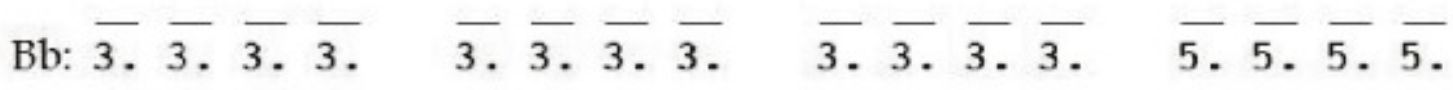

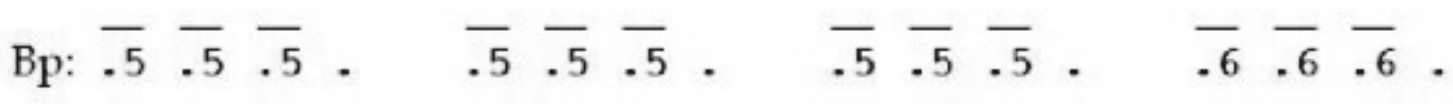

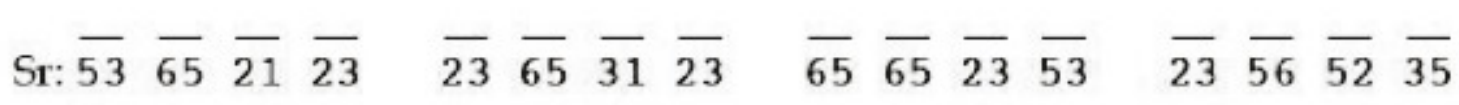

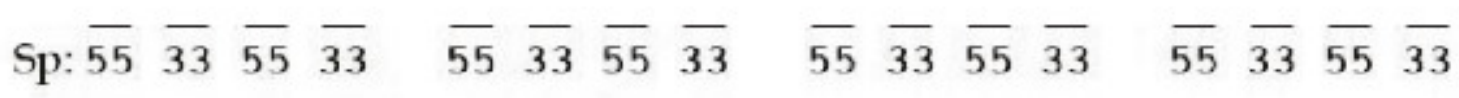

Keterangan:

Teknik atau cara permainan Bonang yaitu kempyung, serta antara Bonang Barung dan Bonang Penerus yaitu pola jalinan atau imbal. Pola permainan pada Saron yaitu nyacah dan pola cacahan tiap pemaian/niyaga bisa berbeda karena mempunyai cengkok sendiri-sendiri.

\section{Garap Dangdut}

Bal: $5 \cdot \hat{3} \cdot 5 \breve{5} \cdot \hat{3} \cdot 5 \cdot \hat{3} \cdot \hat{6} \cdot(5$

$\mathrm{Bb}: \overline{61} \cdot \overline{61} \cdot \overline{61} \cdot \overline{61} \cdot \overline{61} \cdot \overline{61} \cdot \overline{12} \cdot \overline{12} \cdot$ 


$$
\begin{aligned}
& \text { Bp: } \overline{23} \cdot \overline{23} \cdot \overline{23} \cdot \overline{23} \cdot \overline{23} \cdot \overline{23} \cdot \overline{35} \cdot \overline{35}
\end{aligned}
$$

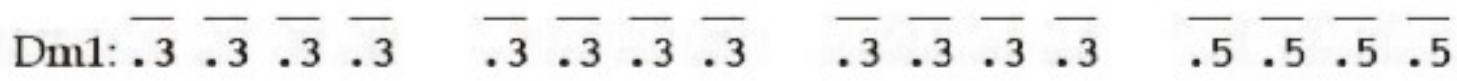

$$
\begin{aligned}
& \operatorname{Dm} 2: \overline{5} \cdot \overline{5} \cdot \overline{5} \cdot \overline{5} \cdot \quad \overline{5} \cdot \overline{5} \cdot \overline{5} \cdot \overline{5} \cdot \quad \overline{5} \cdot \overline{5} \cdot \overline{5} \cdot \overline{5} \cdot \quad \overline{6 .} \overline{6} \cdot \overline{6} \cdot \overline{6}
\end{aligned}
$$

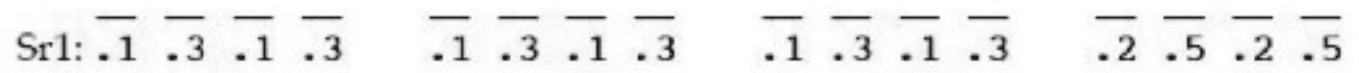

$$
\begin{aligned}
& \text { Sr1: } \overline{2} \cdot \overline{5} \cdot \overline{2} \cdot \overline{5} \cdot \quad \overline{2} \cdot \overline{5} \cdot \overline{2} \cdot \overline{5} . \quad \overline{2} \cdot \overline{5} \cdot \overline{2} \cdot \overline{5} \cdot \quad \overline{1 .} \overline{3} \cdot \overline{1} \cdot \overline{3} . \\
& \begin{array}{lllllllllllllllll}
\text { Sp: } \overline{61} & \overline{23} & \overline{61} & \overline{23} & \overline{61} & \overline{23} & \overline{61} & \overline{23} & \overline{61} & \overline{23} & \overline{61} & \overline{23} & \overline{12} & \overline{35} & \overline{12} & \overline{35}
\end{array}
\end{aligned}
$$

\section{Kempul dan Gong: ada dua macam}

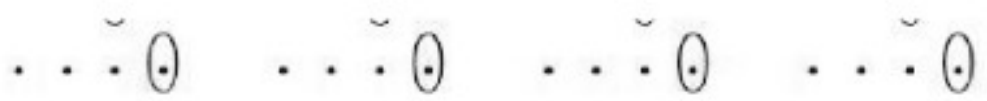

atau

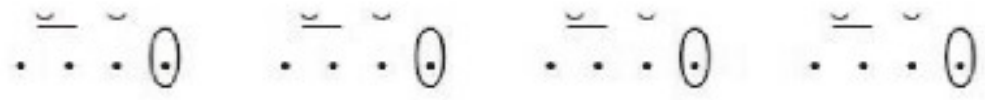

Keterangan:

Pola permainan jalinan pada Bonang dikenal dengan sebutan klenangan dan cara memainkannya disebut dengan plenetan (ditekan). Selain Bonang, pola jalinan juga terjadi pada Demung dan Saron. Pada Saron Penerus, pola permaianannya dikenal dengan istilah peking mlaku. 
Seperti fenomena yang dapat dilihat bahwa Sragenan enak untuk dijogeti, karena Karno dalam proses membuat sekaran pada kendangan juga diikuti dengan jogetan. Untuk menemukan atau membuat pola kendangan selalu dilakukan dua orang dengan satu orang bertindak sebagai peraga ilustrasi jogetan. Dalam hal ini biasanya dilakukan Karno bersama kakaknya dan yang menjadi peraga gerak tarinya adalah Karno.

Setelah menemukan format bentuk sajian dan musikalisasi yang sudah diterapkan ke dalam garapan, kemudian Karno membuat lagu yang berjudul Goyang Pinggul. Begitu karya lagu tersebut jadi, Karno kembali membuat beberapa karya lagu lagi, namun yang menjadi populer di masyarakat pada tahun 1984 yaitu berjudul Rèwèl dan Jamu Jawa. Kedua lagu tersebut menjadi hits karena perekaman yang dilakukan oleh Karno di setiap pentas yang kemudian hasil rekaman tersebut diputar oleh operator sound system di tempat hajatan lain. Hal tersebut terjadi karena perekaman yang dilakukan bukan merupakan rekaman profesional, melainkan hanya meminta bantuan operator sound system untuk merekam.

Evaluasi selalu dilakukan setelah hasil perekaman didengar kembali untuk mencari bagian musik yang perlu mendapatkan pembenahan. Begitu seterusnya yang dilakukan hingga akhirnya tanpa disadari bahwa karyakarya Karno sudah beredar dan diketahui masyarakat luas terutama masyarakat Sragen.

\section{Konsep Non Musikal : Penampilan Seniman dan Tata Panggung}

Selain memiliki pengaruh dari segi musikal, Karno juga memberi sentuhan terhadap kemasan tampilan secara visual. Memiliki daya tarik secara audio (musikal) saja tidak cukup, namun juga harus diimbangi dengan tampilan visual yang lebih mendukung suatu pertunjukan atau pergelaran karawitan. Dalam sebuah pementasan para penonton tidak hanya mengkonsumsi kemasan musik sebagai menu utama, akan tetapi nilai artistik juga menjadi pendukung yang tidak kalah pentingnya. Berangkat dari gagasan inilah Karno mulai memikirkan bahwa niyaga harus berseragam ketika pentas agar terlihat menarik dan kajèn (dihargai). Hal ini tak lepas dari kebiasaan sebelumnya seperti dalam pertunjukan Karawitan Gongpo bahwa para pengrawit hanya berpakaian sekedarnya yang dianggap sudah pantas. Penerapan ide gagasan bahwa para niyaga harus berseragam dia mulai melalui kelompok atau grup rombongannya yang kemudian mulai diikuti oleh kelompokkelompok lain. 
Nilai visual lain yang konsepnya dia pelopori adalah mengenai tata letak panggung untuk perangkat gamelan dan menjadi tempat pengrawit dalam menyajikan gending-gending atau lagu. Ketika kelompok karawitannya ditanggap, Karno menghendaki agar dibuatkan panggung. Dengan belum adanya suatu referensi dan sebagai percobaan yang pertama, panggung yang dibuatkan oleh yang punya hajat ternyata terlalu tinggi sehingga membuat para tamu undangan ketika menonton menjadi kurang nyaman. Berdasarkan pengetahuan selama menempuh pendidikan dan menanggapi kasus tersebut, selanjutnya Karno menjelaskan ukuran tinggi panggung yaitu tidak terlalu rendah dan tingginya juga tidak melibihi ketinggian duduknya tamu undangan.

Pertimbangan ukuran tersebut berdasarkan tingkat kenyamanan tamu undangan sebagai penonton, serta yang menjadi alasan utama Karno yaitu kedudukan pengrawit harus sejajar dengan penonton. Hal yang Karno pertimbangkan merupakan sebuah nilai filosofis dari bentuk sajian terdahulu yaitu karawitan sebagai pengisi hiburan letaknya di bawah (lesehan) dan hanya beralaskan tikar. Berdasarkan penataan sajian tersebut Karno beranggapan bahwa niyaga atau pelaku seniman karawitan tidak ada harganya. Dengan adanya panggung yang disediakan dan dibuat sejajar, maka seperti sudah tidak ada ketimpangan derajat antara niyaga sebagai penghibur dan tamu undangan sebagai penonton atau penikmat.

Sehubungan dengan ide gagasan Karno terhadap panggung dan tata letaknya, memunculkan orang-orang yang memanfaatkan keadaan tersebut dengan menyewakan panggung atau masyarakat sering menyebutnya badhug atau tratag. Masyarakat juga merasa lebih nyaman ketika menonton pertunjukan karawitan yang menggunakan panggung tidak terlalu tinggi. Ketika menggunakan panggung yang tinggi untuk melihat pertunjukan harus sedikit menaikan kepala, selain itu yang kelihatan hanya pengrawit yang posisinya berada di depan. Dengan begitu gagasan mengenai tata panggung tidak hanya berdampak terhadap pengrawit, namun juga berdampak terhadap masyarakat luas baik dari nilai visualisasi hingga nilai ekonomi. Masyarakat yang notabenya menjadi pemilik hajat juga menyadari akan pentingnya tata panggung sebagai penunjang penampilan hiburan yang akan disajikan.

\section{Proses Berkarya}

Setiap karya sudah tentu merupakan hasil dari sebuah pemikiran sang pengkarya. Dalam membuat karya, inspirasi sangat 
penting untuk membangun, membentuk serta mengkonsep agar menghasilkan sebuah karya yang diapresiasi oleh orang lain. Selain menimbulkan perasaan puas bagi pengkarya, bisa jadi sebaliknya dapat memicu seseorang untuk tetap terus berkarya sebagai bentuk rasa ketidak puasan. Sumber inspirasi pun bermacammacam dan bahkan sesuatu yang sederhana bisa menjadi sumber inspirasi dalam berkarya, seperti keadaan yang terjadi dalam diri Karno. Hal-hal kecil di sekitarnya dijadikan sumber inspirasi dalam pembuatan karya lagu, bahkan beberapa lagu atau gending-gending Sragenan ciptaannya terlahir dari keadaan tersulit dalam hidupnya. Musibah yang menimpa keluarganya mampu memunculkan ide gagasan untuk membuat karya dengan kemampuan mencipta lagunya.

Karya lagu yang tercipta dan berangkat dari sebuah musibah yang menimpa keluarganya, tanpa disadari mampu menjadi sebuah karya fenomenal dan terkenal di masanya. Terdapat dua lagu yang menjadi hits dari album hasil perekaman perekaman pada tahun 1984. Kedua lagu tersebut berjudul "Rèwèl" dan "Jamu Jawa" yang keduanya sama-sama diciptakan dari peristiwa istrinya ke luar masuk rumah sakit. Ketika pikiran dihadapkan dengan keadaan yang mungkin untuk sebagian orang membutnya kurang tenang, namun Karno dapat menyalurkan pikirannya untuk membuat lagu.

Karya lagu lain yaitu berjudul "Ireng Manis” juga merupakan karya ciptaannya yang merupakan sebuah bentuk penggambaran dirinya sendiri. Sebagai respon terhadap lingkungan sekitar, Karno membuat sebuah lagu berjudul "Boymin" yang menceritakan seorang anak gembala di desanya. Judul lagu tersebut dibuat "Boymin" karena kata "Boy" merupakan salah satu bahasa asing yang memiliki arti seorang anak laki-laki dan tambahan "min" merupakan salah satu sebutan nama dalam masyarakat Jawa.

Setelah proses penulisan syair atau lirik lagu, selanjutnya Karno melakukan penulisan notasi. Karno menceritakan bahwa dalam menulis notasi tidak sesulit ketika menulis lirik, sehingga proses penulisan notasi lebih cepat dibandingkan dengan menulis syair. Penulisan syair yang dilakukan Karno biasanya membutuhkan waktu minimal 2 minggu, bahkan sampai berbulan-bulan sedangkan menulis notasi hanya 4-7 hari. 82 Waktu terlama Karno dalam menulis syair yaitu 3 bulan karena menentukan sebuah judul terlebih dahulu. Menjadi lebih sulit dalam menulis syair lagu ketika Karno sudah menetukan judul lagu. Begitu kerangka lagu atau gending terbentuk, Karno mengadakan latihan dengan kelompok karawitan "Sekar Puri” 
yang dia pimpin. Proses latihan yang dilakukan dibarengi dengan proses pencarian sekaran yang dilakukan Karno dengan saudaranya.

Selama masa hidupnya sampai saat ini Karno telah memiliki karya sebanyak 6 album yang telah masuk dapur rekaman dan beberapa karya lagunya yang tidak terdokumentasikan. Hal ini karena produktifitasnya di awal berkarya bertujuan untuk mengamankan posisi karawitan di tengah masyarakat. Karya Sragenan yang dia ciptakan semakin populer di masyarakat yang berujung didengar oleh produser rekaman. Salah satu karya lagu ciptaan Karno yang sangat populer di awal kemunculan Sragenan berjudul "Rèwèl”.

\section{Daftar Pustaka}

Munandar, Utami. Kreativitas dan Keberbakatan: Strategi Mewujudkan Potensi Kreatif dan Bakat. Jakarta: Gramedia Pustaka Utama, 2002.

Suparno, Slamet. "Kehidupan Karawitan Sragenan pada Akhir Abad XX dan Beberapa Dampaknya”. Surakarta: STSI Surakarta, 1997.

Sudarni. "Perkembangan Karawitan Di Sragen: Kontinuitas Dan Perubahannya: Dekade 70-an”. Surakarta: Skripsi Sekolah Tinggi Seni Indonesia, 2002.

\section{Narasumber}

1. Muhamad Karno KD. (68 tahun), Seniman. Ngarum, Ngrampal, Sragen. 